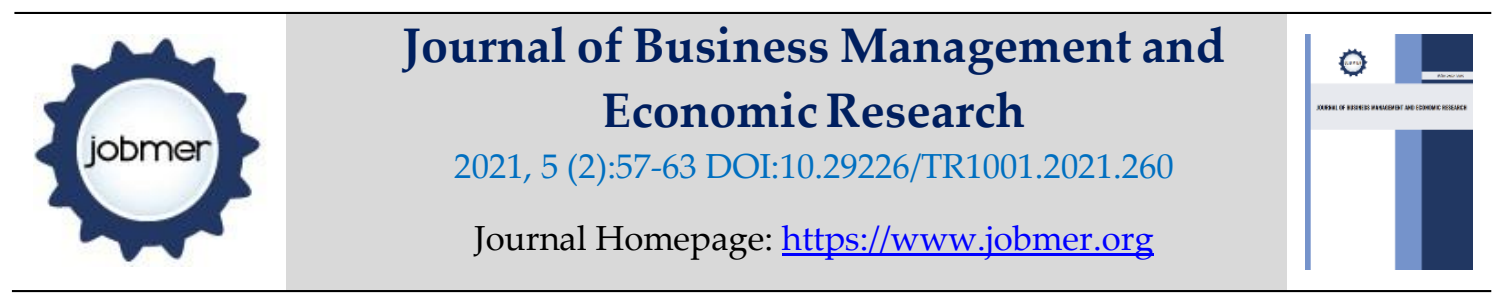

\title{
Does Mainstreaming Board-Level Leadership affect Employee Performance?
}

\author{
Julie Chepkoech Bett \\ School of Business \\ Department of Human Resource Management \\ Rongo University \\ e-mail: betttobit@rongovarsity.ac.ke
}

\begin{abstract}
Leadership is a determinant of the success or failure of any organization. A leader is an individual who induces others and guides them to execute particular duties and to give their best towards achieving the desired goals. Leadership style is a pattern and approach of providing guidance, implementing plans, and motivating people. The role of a leader is critical for the survival and progress of an organization. Leadership helps in developing the organization's objectives, values, and vision. Besides the leadership style of top management, there are the roles of Board of Directors that have a significant impact on organizational performance. The alignment between Board of directors' roles and top management leadership style should be taken into consideration because ineffective coordination between them will influence the organizational performance.
\end{abstract}

Keywords: Leadership, mainstreaming, employee performance

\section{Introduction}

The importance of the mainstreaming of health and safety measures at work cannot be overstated. According to Decenzo \& Robbins (2003) there are approximately 20 million work related injuries each year, 390,000 work related illnesses and 100,000 work related deaths, thus employer has both a moral and a legal obligation to ensure that his employees work in both a safe and healthy environment. Morally no worker should be forced to work in an environment where his welfare is at risk. It also makes good business sense to ensure that workers are both safe and healthy during working hours. Sick or injured workers lead to a drop in production and a subsequent loss of profits thus with increased SHE awareness of employees there is bound to be conflicts resulting from the unwillingness on part of workers to perform certain difficult tasks on the ground of health and safety and environmental concerns. Thus, it is necessary to put in place the necessary procedures to deal with any occurrence (Unilever 2013).

Dangerous working conditions may influence not only employees' performance and work outcomes. Muchinsky (1993). Moral issues aside, there are strict laws and regulations governing the integration of health and safety measures at work as stipulated by the employment act in the constitution of Kenya and other countries, and should an employer transgress these requirements he could find himself being prosecuted and having to pay out large sums in compensation. Good work practices effectively pay for themselves as production remains free from disruption, insurance costs are 
minimized, the workforce remains contented, and customers are delighted with a regular and prompt supply of fulfilled orders (Heinrich, 2009).

In the United Kingdom the Health \& Safety Executive (HSE) are in charge of the integration of health and safety regulations in the workplace. The HSE not only enforce these regulations but will also prosecute employers when they are contravened. While this is very necessary, it puts an enormous strain on employers whose first concern, quite naturally, is to run their businesses as efficiently as possible (Smith 2001). While the HSE produces plenty of information on the regulations, which are often updated, the typical busy employer or manager often has little time to read through them, let alone fully understand them. It is because of this that agencies have emerged that advise employers, managers, and key employees just what the law demands and how to comply by keeping your work premises and practices as safe as possible. These agencies also run courses on various aspects of health and safety, many of which are certified. (Alvin, 2002).

Muchinsky (1993), there are several categories of accidents' causes. First, accidents may occur due to worker's personal characteristics or lack of attention. Second, alertness and stress can be determinants of work accidents. Korman (1977) states that Keenan, Kerr, and Shermon (1951) concluded that the increasing feeling of control over working environment or increased feeling of self-esteem and competence will reduce the likelihood of accidents.

There are reasons why accidents happen. Something goes wrong somewhere. It may take some thought, and maybe the help of friends or other trained people, to figure out what went wrong, but an accident always has a cause, a reason why. Once it is determined why an accident happened, it is possible to prevent future incidents. There is need for some basic facts and perhaps some help from others who already know some of the answers and also a plan to prevent accidents (Alvin, 2002).

It is not difficult to develop such a plan. Basically, the plan should address the types of accidents and health hazard exposures that could happen in your workplace. Because each workplace is different, the program should address the specific needs and requirements. There are four basic elements to all good safety and health programs. These are as follows: Management Commitment and Employee Involvement: The manager or management team leads the way, by setting policy, assigning, and supporting responsibility, setting an example, and involving employees. Worksite Analysis: The worksite is continually analyzed to identify all existing and potential hazards. Hazard Prevention and Control: Methods to prevent or control existing or potential hazards are put in place and maintained. Training for Employees, Supervisors and Managers: Managers, supervisors and employees are trained to understand and deal with worksite hazards. Regardless of the size of the business, one should use each of these elements to prevent workplace accidents and possible injuries and illnesses (Lazarus, 2004).

Limitation of laboratory facilities statistical and research training have been an impediment to the carrying out of occupational health surveys in Kenya as in other developing countries. According to 2000 statistics, tea factories in Kenya employ more than twenty thousand employee and the nature of the work exposes the workers to serious occupational health hazards which include the moving machines such as belt conveyors, rollers, pulley, steam heat from the boilers, dust from the dried tea and fire from the electricity (Munavu 1985).

The trend for leading organizations to integrate health and safety into the mainstream management has sparked a search for new accident causation models. Reason (2000) put up one such model. The 
organizational factors in Reason's model include resource allocation, health and safety goals, delegation of responsibility and authority, workplace design, procurement of equipment etc. These are communicated throughout the organization as workplace factors, such as policies and procedures, work schedules, training etc. These factors affect the workers and may influence them to cut corners to meet an urgent deadline or to assume that a key maintenance action can be left for someone else to carry out.

\section{Theoretical Framework}

The study was based on Heinrich's Domino theory. Heinrich's Domino Theory states that accidents result from a chain of sequential events, metaphorically like a line of dominoes falling over. When one of the dominoes falls, it triggers the next one, and the next but removing a key factor such as an unsafe condition or an unsafe act prevents the start of the chain reaction. According to Heinrich, all incidents directly relate to unsafe conditions and acts, which he defines as unsafe performance of persons, such as standing under suspended loads horseplay, and removal of safeguards; and mechanical or physical hazards such as unguarded gears and insufficient light.

Heinrich mentions five metaphorical dominoes labeled with accident causes. They are Social Environment and Ancestry, Fault of Person, Unsafe Act or Mechanical or Physical Hazard unsafe condition, Accident, and Injury. Heinrich defines each of these dominoes explicitly and gives advice on minimizing or eliminating their presence in the sequence.

This theory is by a great extend related to the study in question as it by a great extend explains the factors associated with workplace health and security which in turn affect employee performance. To be fair he does insist that the responsibility lies first of all with the employer. Heinrich specifies that a truly safety-conscious manager will make sure his foremen and workers do as their told and exercise his prerogative and obtain compliance follow through and see the unsafe conditions are eliminated. Heinrich's remedy for such non-compliance is strict supervision, remedial training, and discipline. According to the Domino Theory, if you want to prevent incidents related to health and safety at workplace, just remove one of the metaphorical dominoes. Such simple solutions usually mean that implementing recommendations generated by this model is no problem, and everybody goes home at the end of the day feeling as though they have accomplished something.

\section{Research methodology}

The study employed a descriptive cross-sectional survey (Kothari 2003). Major purpose of descriptive research is stating of affairs as they exist at present. This approach seeks to collect data without manipulating the research variables or the respondents in an attempt to get the perception of the respondents the effects of mainstreaming health and safety measures on employee performance at workplace. Inferences about relations among variables are made, without direct intervention from concomitant variation of independent and dependent variables.

The descriptive research design gave an opportunity to gain insights into the study population and the variables being studied. Additionally, the design allowed use of inferential statistics to establish the significant relationships between the dependent and the independent variables (Hair et al., 2007).

The study was undertaken within the Tea industry (KTDA). Kebirigo factory located in Nyamira County Nyanza Province of Kenya Kebirigo division which lies to the west of Mugirango Constituency it borders Bomet to the East, Narok to the South, Kisii to the West, HomaBay to the 
North, and Kericho to the North East. It constitutes 3 constituencies (Kitutu Masaba, West Mugirango and North Mugirango Borabu). Borabu, Manga, it has a total population of 598.252; 131,039 households and covers an area of 899.3 SQ.

\section{Demographic Information}

Analysis of the demographic information of the employees focused on establishing among other characteristics, their age, gender, marital status, and terms of employment, working experience and level of education. These characteristics were considered fundamental to assessment of employee's views with regards to mainstreaming of health and safety measures at the workplace.

First, respondents were asked to indicate their age. Age was viewed fundamental in employee performance since several studies reveal that age has an impact on employee performance (Posthuman \& Campion, 2009). As shown in Table 4.1, which presents the demographic information of employee respondents, most of the employees (48.1\%) were aged between 30 to 35 years. This was followed by employees in the age bracket 25-30 (36\%) and those in the age interval $35-40(13 \%)$ respectively. Only $2.6 \%$ of employees were aged above 40 years.

The distribution of respondents across gender revealed that $74 \%$ of them were male while only $26 \%$ were women. A majority of these respondents (89.6\%) were married. Regarding terms of employment, the study revealed that a majority of the employees (62.3\%) were hired on seasonal or temporal basis. A sizeable proportion (35.1\%) was however on permanent employment. The working experience distribution revealed that most employees $(66.2 \%)$ had been working for less than 5 years, $24.7 \%$ had an experience of between 5-10 years. Only $9.1 \%$ had an experience above 10 years. The dominant level of education among employees was found to be secondary school level (63.6\%). A good proportion had a university or college level (28.6\%).

\section{Table 1. Employees Demographic Information}

\begin{tabular}{|c|c|c|c|}
\hline \multirow{2}{*}{$\begin{array}{l}\text { Demographic characteristic } \\
\text { Age }\end{array}$} & Category & \multirow{2}{*}{$\frac{f}{28}$} & \multirow{2}{*}{$\begin{array}{r}\% \\
364\end{array}$} \\
\hline & $25-30$ & & \\
\hline & $30-35$ & 37 & 48.1 \\
\hline & $35-40$ & 10 & 13.0 \\
\hline & Above 40 & 2 & 2.6 \\
\hline & Total & 77 & 100.0 \\
\hline \multirow[t]{3}{*}{ Gender } & Male & 57 & 74.0 \\
\hline & Female & 20 & 26.0 \\
\hline & Total & 77 & 100.0 \\
\hline \multirow[t]{3}{*}{ Marital status } & single & 8 & 10.4 \\
\hline & Married & 69 & 89.6 \\
\hline & Total & 77 & 100.0 \\
\hline \multirow[t]{4}{*}{ Terms of employment } & Permanent \& pensionable & 27 & 35.1 \\
\hline & Seasonal/temporary & 48 & 62.3 \\
\hline & Contract & 2 & 2.6 \\
\hline & Total & 77 & 100.0 \\
\hline \multirow[t]{4}{*}{ Working experience } & Less than 5 years & 47 & 66.2 \\
\hline & $5-10$ years & 19 & 24.7 \\
\hline & $11-15$ years & 7 & 9.1 \\
\hline & Total & 77 & 100.0 \\
\hline \multirow[t]{5}{*}{ Highest level of education and training attained } & Primary & 5 & 6.5 \\
\hline & Secondary & 49 & 63.6 \\
\hline & High school & 1 & 1.3 \\
\hline & University/college & 22 & 28.6 \\
\hline & Total & 77 & 100.0 \\
\hline
\end{tabular}


The finding that most of the employees are aged between 25-40 years is consistent with beliefs which indicate that relative to younger workers, older workers have lower physical abilities, less energy (Parson \& Mayne, 2001), less competence (Kite, Stockdale, Whitney \& Johnson, 2005), and more stress. The finding that most employees have a working experience of less than 5 years reflects the finding showing that many of the employees are on seasonal or temporal employment.

\section{The Effect of Mainstreaming Board-Level Leadership on Employee Performance}

Table 2. Employee Perceptions on Mainstreaming of Board Level Leadership at the Workplace

\begin{tabular}{|c|c|c|c|c|}
\hline Response items & $\mathbf{M}$ & SD & Skewness & Kurtosis \\
\hline $\begin{array}{l}\text { 1. The company has an independent committee at the } \\
\text { board-level dedicated to HS oversight }\end{array}$ & 4.38 & .563 & -.630 & 2.196 \\
\hline $\begin{array}{l}\text { 2. The members of this committee have established a } \\
\text { process to identify workplace stressors, and hazards }\end{array}$ & 4.32 & 1.032 & -1.654 & 2.102 \\
\hline $\begin{array}{l}\text { 3. The committee has an established and maintained } \\
\text { systems for reporting and investigating nonconformance by } \\
\text { management }\end{array}$ & 4.30 & .608 & -.615 & 1.408 \\
\hline $\begin{array}{l}\text { 4. The committee is accountable for identifying and } \\
\text { understanding the risks and opportunities associated with } \\
\text { HS }\end{array}$ & 4.08 & 1.156 & -1.415 & 1.511 \\
\hline $\begin{array}{l}\text { 5. The committee ensures that HS responsibilities and } \\
\text { expectations have been established for the company and are } \\
\text { communicated to all levels }\end{array}$ & 3.95 & .985 & -1.165 & 1.525 \\
\hline $\begin{array}{l}\text { 6. The committee is supported with adequate resources to } \\
\text { be able to carry out their HS mandate }\end{array}$ & 3.36 & 1.356 & -.434 & -.958 \\
\hline $\begin{array}{l}\text { 7. The committee established a steering committee or } \\
\text { working group, which includes workers and their } \\
\text { representatives, in order to establish HS priorities }\end{array}$ & 2.39 & 1.183 & .565 & -.447 \\
\hline $\begin{array}{l}\text { 8. The committee has a process to identify market or } \\
\text { regulatory pressures that may impact corporate HS } \\
\text { standards and objectives }\end{array}$ & 2.09 & 1.289 & 1.074 & -.038 \\
\hline
\end{tabular}

1-strongly disagree; 2-disagree; 3-moderately agree; 4-agree; 5-strongly agree

Results gathered from management interview and employee questionnaire imply that management of Kebirigo Tea Factory have endeavored to constitute an independent board level committee that has the mandate to handle HS issues in the company. Terms of reference for this committee include HS oversight and accountability for identification of risks and opportunities associated with HS. However, despite the necessity of resources for this committee, it would appear that the committee is not supported adequately in terms of resources hence some key functions such as establishing a steering committee have not been satisfactorily achieved.

\section{Employee Perception on Mainstreaming Board Level Leadership in HS Matters in Kebirigo Tea Factory}

Employee perceptions regarding mainstreaming board level leadership on HS matters were measured using a total of eight questionnaire items. Respondents were asked to indicate their agreement or disagreement with the items which reflected mainstreaming of board level leadership 
in HS matters. Responses were once again elicited on a five-point scale ranging from 1-strongly disagree to agree 5-strongly. The mean response scores and corresponding standard deviations were computed and used in capturing employee perceptions. In addition, skewness and Kurtosis values were computed and used in exploring the distribution of employee responses about the mean scores. Results presented in Table 4.5 reveal that respondents appeared to agree with most of the items. In addition, the distribution of responses was symmetrical about the mean responses scores.

In particular, respondents tended to agree that the company has an independent committee at the board level dedicated to HS oversight $(\mathrm{M}=4.38, \mathrm{SD}=0.563)$; that the members of this committee have established a process of identifying workplace stressors and hazards $(\mathrm{M}=4.32, \mathrm{SD}=1.032)$; that the committee has an established and maintained system for reporting and investigating nonconformance $(\mathrm{M}=4.30, \mathrm{SD}=0.608)$; that the committee is accountable for identifying and understanding the risks and opportunities associated with HS $(\mathrm{M}=4.08, \mathrm{SD}=1.156)$; and that the committee ensures that HS responsibilities and expectations have been established for the company and are communicated to all levels $(\mathrm{M}=3.95, \mathrm{SD}=0.985)$. Respondents however, tended to moderately agree that the committee is supported with adequate resources to be able to carry out their HS mandate $(\mathrm{M}=3.36, \mathrm{SD}=1.356)$.

On the other hand, respondents tended to disagree that the committee established a steering committee or working group, which includes workers and their representatives in order to identify HS priorities $(\mathrm{M}=2.39, \mathrm{SD}=1.183)$; and that the committee has a process to identify market or regulatory pressures that may impact corporate HS standards and objectives ( $\mathrm{M}=2.09, \mathrm{SD}=1.289$ ). 


\section{References}

Alvin R. (2002), The Measure of Man \& Woman: Human Factors in Design, A human factors design manual, 28(5), 278-295.

Decenzo, D.A\& Robbins, S.P. Third Edition Personnel/ Human Resource Management

Hair, J., Anderson, R., Tatham, R., and Black, W. (1998). Multivariate data analysis (5 ${ }^{\text {th }}$ Ed.).

London: Prentice-Hall International

Heinrich, H.W. (2009) Industrial Accident Prevention. McGraw Hill: New York.

Kothari C.R. (2003). Research methodology, Methods, and techniques. New Delhi: New age International Publishers.

Korman, A.K. (197) Industrial and organizational psychology. Englewood Cliffs, N.J.:

Prentice-Hall

Lazarus, R.S. \&Folkman, S. (2004) Stress, Appraisal and Coping, London: Springer Publications

Labour Force Survey2003/04 Self-Reported Work-Related Illness.

Munavu R.M: (1985) A note on industrial Chemicals in Kenya. Paper presented to Taskforce on Chemicals Management Kenya

Martin, K.C (2006) African Newsletter on Occupational health and Safety 2006

Muchinsky, P. M. (1993). Psychology applied to work: an introduction to industrial and organizational psychology. London: Chapman \& Hall 